\title{
Analysis of Antecedents Visit Intention on Thousand Islands Tourism Moderated by Travel Motivation and Employee Education and Training on Improving Performance in Providing Services
}

\author{
Mohamad Surya Atmaja, Nico Lukito* \\ Magister Management Program \\ Trisakti University \\ Jakarta, Indonesia \\ *nicolukito@trisakti.ac.id
}

\begin{abstract}
The purpose of this study is to analyze Antecedents Visit Intention in Kepulauan Seribu Tourism as moderated by Travel Motivation. The problems of this research are : Is there an effect of Travel Motivation on Visit Intention, the influence of constraints on Visit Intention, the effect of perceived travel risks on Visit Intention, can Travel Motivation moderate the effect of perceived travel risks on Visit Intention, Travel Motivation can moderate the effect of constraints on Visit Intention. This research uses explanatory type using quantitative. The sample used for this study was 118 respondents living around Jakarta, Bogor, Depok, Tanggerang, Bekasi JABODETABEK. Data collection used in this study is a survey that must answer the questions given by researchers. Analyze with descriptive analysis and path analysis. The results of the questionnaire were processed using a Structural Equation Model (SEM).The results of hypothesis testing indicate that the variable dimensions Travel Motivation does not have a positive influence on Visit Intention, Constraints have a positive influence on Visit Intention, Perceived Travel Risk has a positive influence on Visit Intention, Travel Motivation can moderate the effect of Perceived Travel Risk on Visit Intention, Travel Motivation can moderate the influence of constraints on Visit Intention.This study uses a sample size of 118 respondents which may not represent the total view of the community. The next researcher must emphasize post-visit evaluation to investigate the role of Travel Motivation moderation in Risk Perception, Constraints and Behavioral Intention.The conceptual variable framework in this study adds the construct of using Travel Motivation as an independent variable on Visit Intention, Travel Motivation as a moderation of the Constraints and Perceived Travel Risk variables.
\end{abstract}

\section{INTRODUCTION}

As the capital city of Indonesia, DKI Jakarta Province, has a lot of tourism potential that is not less competitive with other areas in other parts of Indonesia, there are many kinds of tourist attractions that can be enjoyed by tourists who want to visit DKI Jakarta, including old historic buildings, dark tourism, which is a tour that provides experiences about dark and creepy history, to marine tourism located in North Jakarta in the Jakarta Administration District, the Kepulauan Seribu, which offers the charm of beaches and small islands as well as various water rides because its beauty is still maintained.

The islands in the Kepulauan Seribu are actually not like the names of 1000 islands, but as many as 112 islands. Of the total 112 islands consisting of small islands and large islands; classified back into two types of islands, namely island residents and resort islands. The Administration of the Kepulauan Seribu District Administration is divided into 2 Districts and 6 Sub-Districts, the two Districts are the South Kepulauan Seribu District, and the North Kepulauan Seribu District [1].

The Kepulauan Seribu have a special charm that attracts tourists to visit. Researchers argue that motivation has the most importance in travel behaviour such as choice of destination and visit intention [2]. With the large number of visitors, it further motivates potential visitors to visit the Kepulauan Seribu.

Keywords-travel motivation, constraint, perceived travel risk, visit intention, Kepulauan Seribu 
TABLE I. N N NUMBER OF TOURIST Visits TO LEADING TOURIST ATTRACTIONS IN 2015-2018

\begin{tabular}{|c|c|c|c|c|c|}
\hline No & Tourist Attractions & Unit & Foreigner & Domestic & Total \\
\hline (1) & $(2)$ & (3) & (4) & (5) & (6) \\
\hline 1 & Pulau Anyer (Resort) & Person & 3.699 & 18.504 & 22.203 \\
\hline 2 & Pulau Bidadari (Resort) & Person & 9 & 440 & 449 \\
\hline 3 & Pulau Kotok Tengah (Resort) & Person & 336 & 1.700 & 2.036 \\
\hline 4 & Pulau Sepa (Resoort) & Person & 8.605 & 8.646 & 17.251 \\
\hline 5 & Pulau Putri (Resort) & Person & 4.198 & 6.611 & 10.809 \\
\hline 6 & Pulau Untung Jawa & Person & 120 & 160.213 & 160.333 \\
\hline 7 & Pulau Pramuka & Person & 2.106 & 94.980 & 97.086 \\
\hline 8 & Pulau Tidung & Person & 1.731 & 151.312 & 153.043 \\
\hline 9 & Pulau Harapan & Person & 480 & 64.733 & 65.213 \\
\hline 10 & Pulau Kelapa & Person & 153 & 37.152 & 37.305 \\
\hline 11 & Pulau Lancang \& Pari & Person & 2.051 & 131.220 & 133.271 \\
\hline 12 & Pulau macan (Resort) & Person & 1.924 & 2.897 & 4.821 \\
\hline 13 & Pulau Kotok (Resort)* & Person & 336 & 1.700 & 2.036 \\
\hline 14 & Pulau Pelangi (Resort)* & Person & 779 & 2.922 & 3.701 \\
\hline \multirow[t]{5}{*}{15} & Pulau Pantara (Resort)* & Person & 1.890 & 65.561 & 67.451 \\
\hline & Total & Person & 28.417 & 748.591 & 777.008 \\
\hline & 2017 & Person & 27.637 & 769.581 & 797.218 \\
\hline & 2016 & Person & 20.932 & 759.027 & 779.004 \\
\hline & 2015 & Person & 10.836 & 801.421 & 812.257 \\
\hline
\end{tabular}

Source: The Seribu Islands Administration for Tourism and Culture Sub-Department.

Based on table 1 above, we can see a trend that shows that domestic tourists fluctuate every year. The number of leading tourist sites in the Kepulauan Seribu that can be visited has its own charm. The number of tourist arrivals in the Kepulauan Seribu has fluctuated every year. From the existing data, it can be seen that the number of domestic tourists was 748,591 and foreign tourists as many as 28,417 in 2018 , so that the total number of tourists in 2018 was 777,008 , decreasing by $2.6 \%$ from 2017. In 2017, it increased by $2.2 \%$ to 797,218 from 2016 as many as 779,004 . However, in 2016 there was a significant decrease of $4.2 \%$ from 2015 of 812,257 [1,3-5].

Domestic tourist data shows a fluctuating trend every year. The number of tourists each year has increased in 2016 by $48 \%$ from 2015, and in 2017 by 24\%, and in 2018 by 3\%. From the percentage increase in the number of foreign tourists from year to year, the increase is slightly (not significant) [1,3-5] participate and enjoy recreational activities [6]. Perceived Travel Risk, namely consumer perceptions of possible risks from actions that can create hazards so that it will influence travel decisions from the perceived danger if it has exceeded the limit. However, Roehl and Fesenmaier [7] argue that a situation in which the only possible outcome is the loss of some magnitude is not a risk. In travel decision making, perceived risk is very important because of its ability to change decisions [8].

Visit Intention is a perception felt by tourists to visit certain destinations in a certain period [9]. Visit Intention is also considered a mental process and a transformation from Travel Motivation into behavior [10]. Travel intention for tourists can be seen by developing insights into issues such as attitudes or perceptions of goals with the main key being constraits, and the perceived level of perceived personal control over the resources needed to achieve targeted behavior [11].
Tourist visits to tourist attractions are supported by tourism management including travel management that provides the best service to tourists. Travel parties who accompany tourists are the key to impressing a tourist visit. Therefore a competent and understanding companion is needed in travel management. One of the ways to form and improve the ability of travel employees is to use educational and training activities for employees

Previous research has shown that there is an effect of education and job training and work motivation on employee performance $[12,13]$. So it can be concluded that trained and competent employees will improve performance so that it affects the intensity of visiting a tourist spot because the services provided are good.

\section{REVIEW THEORY AND STUDY RESEARCH RESULTS}

Motivation is a condition that comes from the psychological of an individual which arises because of the desire to take an action. According to $\mathrm{Li}$ and Cai [2], motivation is a tendency or frame of mind that arises out of need so that it becomes an impetus for an individual to take various types of actions to meet those needs. In tourism, motivation is a psychological / biological need that awakens, directs, and integrates a person to behave and do activities [14]. Travel Motivation is a driving factor that can influence tourists to show tourist behavior [15].

Travel constraints are a key factor that keeps people from starting or continuing a journey [16]. Travel constraints refer to the factors that hinder travel on an ongoing basis, result in the inability to increase or maintain the frequency of travel, cause the inability to initiate trips, and result in negative effects on the quality of the journey [17]. In other words, Travel Constraints are factors that limit the desire to spend leisure 
time and inhibit or prohibit people's desire to participate and enjoy recreational activities [6]. Perceived Travel Risk, namely consumer perceptions of possible risks from actions that can create hazards so that it will influence travel decisions from the perceived danger if it has exceeded the limit. However, Roehl and Fesenmaier [7] argue that a situation in which the only possible outcome is the loss of some magnitude is not a risk. In travel decision making, perceived risk is very important because of its ability to change decisions [8].

Visit Intention is a perception felt by tourists to visit certain destinations in a certain period [9]. Visit Intention is also considered a mental process and a transformation from Travel Motivation into behavior [10]. Travel intention for tourists can be seen by developing insights into issues such as attitudes or perceptions of goals with the main key being constraits, and the perceived level of perceived personal control over the resources needed to achieve targeted behavior [11]

\section{FORMULATION OF HYPOTHESIS}

Researchers argue that motivation has the most importance in travel behavior such as choice of destination and visit intention [2,18]. Kale and Weir [19] found that would-be Western travelers feel positively about India's culture and history, exotic environments, unique customs, and food. Huang and Hsu [18] found a positive effect of motivation (new and relaxed enjoyment) on attitudes toward return visit intentions. Lam and Hsu [20] measured motivation as behavioral beliefs and subjective norms and found motivation to predict in choosing goals. Jang et al. [10] found Taiwan seniors motivated by the new quest were more likely to travel to Hong Kong. Leong et al. [21] found that nostalgia as a motivational boost had a significant positive effect on an individual's future visit intentions. Based on this research, a hypothesis can be formulated as follows:

H1: Travel Motivation has a positive effect on Visit Intention.

Potential travelers adopt constraint negotiation measures to minimize their influence in travel decision making $[17,18]$. Early literature such as Blazey [22] defined a lack of money, time, family support or interest, and ill health as perceived constraints affecting travel intentionsprospective American students had a negative effect on their travel intentions. Chen et al. [23], while examining the mediating effect of destination images on travel constraints and visit intention, found a significant negative relationship between visit intention and travel constraints. Based on this research, a hypothesis can be formulated as follows:

\section{H2: Constraints have a positive effect on Visit Intention.}

Perceived risk was first described in consumer purchases as physical, financial, psychological, social, and time risks and was adopted in travel purchases [24]. Roehl and Fesenmaier [7] explored these risks in travel research as pre- and post-trip risks for happy travelers. Subsequently, Fuhs and Reichel [25] conducted an extensive study to identify perceived risks in transit by conducting factor analysis and identifying nine dimensions of risk caused by humans, socio-psychological, quality of service, financial, natural disasters, food safety issues, weather and accidents. Kozak et al. [26] found varying degrees of difference in risk perception among tourists from different cultures. They also found that tourists attributed certain types of risk to certain areas of travel. Hung and Petrick [17] describe information gathering as a tool to minimize risk perceptions among potential travelers. Based on this research, a hypothesis can be formulated as follows:

H3: Perceived Travel Risk has a positive effect on Visit Intention.

Travel constraints are factors that require spending free time and spending or people's desire to enjoy and enjoy recreational activities [6]. Psychological / biological needs that awaken, direct and integrate individual behavior and activities $[14,27,28]$. However, researchers argue that providing precise reasons why many people want to travel and what they want to enjoy, is difficult because of the complex nature of humans [29]. Researchers also argue that motivational drives are influenced by perceived risks and constraints that can change people's travel behavior [30,31]. Previous studies have examined the that moderate role of travel motivation in the context of vacation and travel and found that and a person's choice of destination. Hung and Petrick [17] found that travel constraints for

travel motivation can strengthen or weaken the relationships between different variables. Individuals who score high in risk-taking and sensation-seeking motivation prefer more active, spontaneous, fast and less comfortable vacations [15]. Based on this research, a hypothesis can be formulated as follows:

H4: Travel Motivation can moderate the effect of Perceived Travel Risks on Visit Intention.

In the context of high perceptions of travel constraints, Jackson et al. [32] that travel motivation may have an intervening role in individual decision-making processes and may interact with perceptions of constraints. They also argue that participation in travel activities can be determined by relative motivational strength in relation to perceived constraints. In addition, research shows that highly motivated individuals are less likely to perceive high levels of resistance or they are better prepared to overcome obstacles and are more likely to participate in travel activities [33,34]. Based on this research, a hypothesis can be formulated as follows:

H5: Travel Motivation can moderate the influence of Constraints on Visit Intention.

The following conceptual framework is developed from the research of Mohammad J Khan, Shankar Chelliah, Firoz Khan, Saba Amin [35] and Mohammad J Khan, Shankar Chelliah, Sahrish Ahmed [36]. Travel Motivation, Constraint, Perceived Travel Risk and Visit Intention variables were taken from the research of Mohammad J Khan, Shankar Chelliah, Firoz Khan, Saba Amin [35] and the moderating variable Travel Motivation 
was taken from the research of Mohammad J Khan, Shankar Chelliah, Sahrish Ahmed [36 ] (See Figure 1).

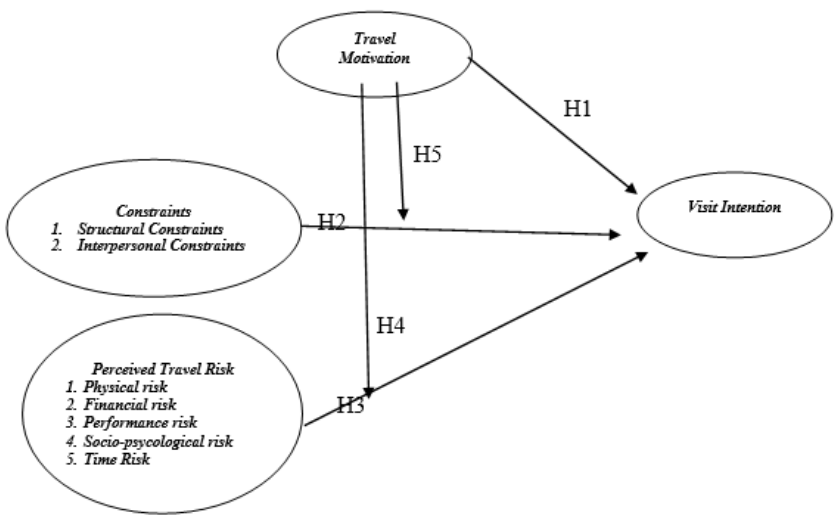

Fig. 1. Conceptual framework.

\section{RESEARCH METHODOLOGY}

\section{A. Population}

In this study, 118 people distributed questionnaires around JABODETABEK for one month in collecting respondent data. The technique used for sampling in this study is purposive sampling technique. Purposive sampling technique is a technique in collecting data based on criteria in a particular study [20]. In this study, the authors used criteria aimed at the community around Jabodetabek. This research in determining the number of samplesto be used is by using the formula from Walpole which is commonly used to determine the size of the sample in the infinite or non-permanent population of the teacher. In calculating the sample using the following formula:

$$
N=\frac{Z^{2 \alpha / 2}}{4 e^{\alpha}}
$$

Where:

$$
\begin{array}{ll}
\mathrm{N} & =\text { Number of Samples } \\
\alpha & =\text { Estimated Level of Trust }(=5 \%)
\end{array}
$$

$\mathrm{e} \quad=$ Alleged error $(\mathrm{e}=9 \%)$

$\mathrm{Z} \quad=$ Normal value

- The first step:

$Z^{2} \alpha / 2=Z^{2} 0,05 / 2$

$=\mathrm{Z}^{2} 0,025$

The $\mathrm{Z}$ value of 0.025 when viewed in the distribution table is 1.96 which is obtained from $(1,9+0,060)$.

- Second step:

$$
\begin{aligned}
N & =\frac{1,96^{2}}{4\left(0,009^{2}\right)} \\
& =\frac{3,8416}{4(0,0081)} \\
& =\frac{3,8416}{0,0324} \\
& =118,567
\end{aligned}
$$

Based on the formula above, the authors took a sample of 118 respondents in this study.

\section{B. Sources and Data Collection Techniques}

The way to collect the data itself is by distributing questionnaires where the content of the questionnaire itself comes from the items of each existing variable and is entered into the Google form. In order for the data obtained to be more valid, it will be added to the start page of Google form some of the required Population and Sample criteria requirements. If they meet the requirements, the respondent can continue filling out the existing questionnaire. Distribution of questionnaires via Whatsapp from December 2019 to February 2020.

\section{RESEARCH RESULTS AND DISCUSSION}

\section{A. Characteristics of Respondents}

The following are the characteristics of the respondents from this study table 2 . 
TABLE II. DEMOGRAPHIC CHARACTERISTICS OF RESPONDENTS

\begin{tabular}{|l|l|l|}
\hline \multicolumn{1}{|c|}{ Characteristics } & \multicolumn{1}{|c|}{ Amount (n) } & \multicolumn{1}{c|}{ Percentage (\%) } \\
\hline Male & & \\
\hline Female & 56 & $47.5 \%$ \\
\hline Total Age & 52 & $52.5 \%$ \\
\hline \multicolumn{1}{|c|}{$\mathbf{1 1 8}$} & $\mathbf{1 0 0 . 0 \%}$ \\
\hline 20-25 Years & 35 & \\
\hline 26-30 Years & 30 & $29,7 \%$ \\
\hline 31-35 Years & 25 & $25,4 \%$ \\
\hline$>$ 36 Years & 28 & $21,2 \%$ \\
\hline Total & $\mathbf{1 1 8}$ & $23,7 \%$ \\
\hline \multicolumn{1}{|c|}{ Last Education } & & $\mathbf{1 0 0 . 0 \%}$ \\
\hline SMA/Equivalent & 21 & \\
\hline Diploma & 9 & $17,8 \%$ \\
\hline S1 & 74 & $7,6 \%$ \\
\hline S2 & 14 & $62,7 \%$ \\
\hline Total & 118 & $11,9 \%$ \\
\hline & & $100.0 \%$ \\
\hline Jakarta & 46 & \\
\hline Bogor & 33 & $46 \%$ \\
\hline Depok & 7 & $28 \%$ \\
\hline Bekasi & 9 & $5,9 \%$ \\
\hline Tangerang & 20 & $7,6 \%$ \\
\hline Outside Jabodetabek & 3 & $16,9 \%$ \\
\hline Total & $\mathbf{1 1 8}$ & $2,5 \%$ \\
\hline
\end{tabular}

\section{B. Hypothesis Test Results}

Testing of the hypothesis is carried out using the Structural Equation Model (SEM) method. The basis of the hypothesis test decision making is to compare the amount of $\mathrm{p}$-value with a level of significance of $5 \%$ (alpha 0.05 ). If the p-value is more than alpha 0.05 then the null hypothesis (Ho) fails to be rejected, which means that there is no significant effect between the two variables and vice versa if the p-value is lower than alpha 0.05 then the null hypothesis $(\mathrm{Ho})$ is rejected table 3.

TABLE III. HYPOTHESIS TESTING RESULTS

\begin{tabular}{|c|c|c|c|}
\hline Hypothesis & Coefficient & P-value & Decision \\
\hline $\begin{array}{l}\text { H1: Travel Motivation has a } \\
\text { positive influence on Visit } \\
\text { Intention }\end{array}$ & 0,370 & 0,196 & $\begin{array}{l}\text { Not } \\
\text { supported }\end{array}$ \\
\hline $\begin{array}{l}\text { H2: Constraint has a } \\
\text { positive effect on Visit } \\
\text { Intention }\end{array}$ & $-0,457$ & 0,000 & Supported \\
\hline $\begin{array}{l}\text { H3: Perceived Travel Risk } \\
\text { has a positive influence on } \\
\text { Visit Intention }\end{array}$ & 0,522 & 0,000 & Supported \\
\hline $\begin{array}{l}\text { H4: Travel Motivation can } \\
\text { moderate the effect of } \\
\text { Perceived Travel Risk on } \\
\text { Visit Intention }\end{array}$ & 0,002 & 0,068 & Supported \\
\hline $\begin{array}{l}\text { H5: Travel Motivation can } \\
\text { moderate the influence of } \\
\text { constraints on Visit } \\
\text { Intention }\end{array}$ & 0,002 & 0,068 & Supported \\
\hline
\end{tabular}

1) Hypothesis 1: Based on the results of statistical testing, it is known that the Estimate of Travel Motivation is 0.370 , meaning that the higher the perception of Travel Motivation, the higher the perception of Visit Intention. The test results show a p-value of $0.196>0.05$ (alpha 5\%), so it is concluded statistically at the 95 percent confidence level there is no positive influence of Travel Motivation on Visit Intention.

2) Hypothesis 2: Based on the results of statistical testing, it is known that the Estimate of Travel Motivation is -0.457 , meaning that the higher the perception of constraint, the higher the perception of Visit Intention. The test results show a pvalue of $0.000<0.05$ (alpha $5 \%$ ), so it is concluded that statistically at the 95 percent confidence level there is a positive influence on Visit Intention.

3) Hypothesis 3: Based on the results of statistical testing, it is known that the Estimate of Perceived Travel Risk is 0.552, meaning that the higher the perception of Perceived Travel Risk, the higher the perception of Visit Intention. The test results show a p-value of $0.000<0.05$ (alpha $5 \%$ ), so it is concluded statistically at the 95 percent confidence level there is a positive influence of Perceived Travel Risk on Visit Intention.

4) Hypothesis 4: Based on the results of statistical testing, it is known that the Estimate of Perceived Travel Risk is 0.002, meaning that the higher the perception of Perceived Travel Risk, the higher the perception of Visit Intention. The test results show a p-value of $0.068<0.01$ (alpha 10\%) using a significant value of $\mathrm{p}$-value $<(10 \%)$ the $\mathrm{p}$-value does not have to be $(5 \%)$ so it is concluded statistically at a 95 percent confidence level. Travel Motivation can moderate the influence of Perceived Travel Risk on Visit Intention.

5) Hypothesis 5: Based on the results of statistical testing, it is known that the size of the Estimate of Constraints is 0.002 , meaning that the higher the perception of Constraints, the higher the perception of Visit Intention. The test results show a p-value of $0.068<0.01$ (alpha 10\%) using a significant p-value $<(10 \%)$ the p-value does not have to be $(5 \%)$ so it is concluded statistically at a 95 percent confidence level. Travel Motivation can moderate the influence of constraints on Visit Intention.

\section{CONCLUSIONS}

Testing of research problems shows that Travel Motivation has no positive influence on Visit Intention, Constraint has a positive influence on Visit Intention, Perceived Travel Risk has a positive effect on Visit Intention, Travel Motivation can moderate the effect of Perceived Travel Risk on Visit Intention, Travel Motivation can moderate the influence of constraints on Visit Intention. The results of this study should be used by management to increase Visit Intention by paying attention to Constraints, Perceived Travel Risk and being moderated by Travel Motivation. In this research, which is a tourism marketing study, this study is expected to be useful for the tourism industry, how to plan marketing strategies based on customer experience in highly competitive tourism business competitions. Further researchers should emphasize post-visit evaluations to investigate the moderating role of Travel 
Motivation on Risk Perception, Constraints and Behavioral Intention. The majority of respondents are in the younger age group and their opinions cannot be generalized to other age groups. In addition, further research is needed in different age groups and geographic areas to establish a generalized research framework.

\section{REFERENCES}

[1] Central Statistics Agency, Administrative District, Kepulauan Seribu, Kepulauan Seribu in Figures. (Report). Jakarta, 2019.

[2] M. Li and L. Cai, "The effects of personal values on travel motivation and behavioral intention," Journal of Travel Research, vol. 51, pp. 473487, 2012.

[3] Central Statistics Agency, Administrative District, Kepulauan Seribu, Kepulauan Seribu in Figures. (Report). Jakarta, 2018

[4] Central Statistics Agency, Administrative District, Kepulauan Seribu, Kepulauan Seribu in Figures. (Report). Jakarta, 2017.

[5] Central Statistics Agency, Administrative District, Kepulauan Seribu, Kepulauan Seribu in Figures. (Report). Jakarta, 2016.

[6] K. Hung and J. Petrick, "Testing the effects of congruity, travel constraints, and self-efficacy on travel intentions: An alternative decision-making model," Tourism Management, vol. 33, pp. 855-867, 2012.

[7] W.S. Roehl and D.R. Fesenmaier, "Risk perceptions and pleasure travel: an exploratory analysis," Journal of Travel Research, vol. 30, pp. 17-26, 1992.

[8] S. Sönmez and A.R. Graefe, "Determining Future Travel Behavior from Past Travel Experience and Perceptions of Risk and Safety," Journal of Travel Research, vol. 37, pp. 171-177, 1998.

[9] T. Ahn, Y. Ekinci, and G. Li, "Self-congruence, functional congruence, and destination choice," Journal of Business Research, vol. 66, pp. 719723, 2013.

[10] S. Jang, B. Bai, C. Hu, and C.M.E. Wu, "Affect, Travel Motivation, and Travel Intention: A Senior Market," Journal of Hospitality \& Tourism Research, vol. 33, pp. 51-73, 2009.

[11] J.R. Sparks and Y. Pan, "Ethical Judgments in Business Ethics Research: Definition, and Research Agenda," Journal of Business Ethics, vol. 91, pp. 405-418, 2010.

[12] N.R. Andayani and P. Makian, "Pengaruh Pelatihan Kerja dan Motivasi Kerja terhadap Kinerja Karyawan Bagian PT. PCI Elektronik International," Jurnal Akuntansi, Ekonomi Dan Manajemen Bisnis, vol. 4, no. (1), pp. 41-46, 2016

[13] Y.Y. Darmawan, W.G. Supartha, and A.G. Rahyuda, "Pengaruh pelatihan terhadap motivasi kerja dan kinerja di Prama Sanur BeachBali. E-Jurnal Ekonomi dan Bisnis Universitas Udayana, 6(3), 1265 1290, 2017

[14] D.B. Park and Y.S. Yoon, "Segmentation by Motivation in Rural Tourism: A Korean Case Study," Tourism Management, vol. 30, pp. 99$108,2009$.

[15] A. Pizam, Y. Neuman, and A. Reichel, "Dimensions of tourist satisfaction with a destination area," Annals of Tourism Research, vol. 5, pp. 314-322, 1978.

[16] D. Kerstetter, I-Yin Yen, and C. Yarnal, "Plowing Uncharted Waters: A Study of Perceived Constraints to Cruise Travel," Tourism Anaysis, vol. 10, pp.137-150, 2005.
[17] K. Hung and J. Petrick, "Developing a measurement scale for constraints to cruising," Annals of Tourism Research, vol. 37, pp. 206-228, 2010

[18] C.H.C. Hsu and S.S. Huang, "Effects of Travel Motivation, Past Experience, Perceived Constraint, and Attitude on Revisit Intention," Journal of Travel Research, vol. 48, pp. 29-44, 2009.

[19] S.H. Kale and K.M. Weir, "Marketing third world countries to the Western traveler: The case of India," Journal of Travel Research, vol. 25 , pp. 2-7, 1986

[20] T. Lam and C.H.C. Hsu, "Predicting behavioral intention of choosing a Travel destination," Tourism Management, vol. 27, pp. 589-599, 2006.

[21] A.M.W. Leong, S-S.Yeh, Y.C. Hsiao, and T.C. Huan, "Nostalgia as Travel motivation and its impact on tourists' loyalty," Journal of Business Research, vol. 68, pp. 81-86, 2015.

[22] M.A. Blazey, "The Differences Between Participants and Nonparticipants in a Senior Travel Program," Journal of Travel Research, vol. 1, 1987.

[23] P-J. Chen, N. Hua, and Y. Wang, "Mediating perceived Travel constraints: The role of destination image," Journal of Travel \& Tourism Marketing, vol. 30, pp. 201-221, 2013.

[24] P.M. Simpson and J.A. Siguaw, "Destination Word of Mouth: The Role of Traveler Type, Residents, and Identity Salienc," Journal of Travel Research, vol. 1, 2008.

[25] G. Fuchs and A. Reichel, "Tourist Destination Risk Perception: The Case of Israel," Journal of Hospitality \& Leisure Marketing, Vol. 14, pp 83-108, 2006.

[26] M. Kozak, J.C. Crotts, and R. Law, "The impact of the perception of risk on international travelers," International Journal of Tourism Research, vol. 9, pp. 233-242, 2007

[27] Y. Yoon and M. Uysal, "An Examination of the Effects of Motivation and Satisfaction on Destination Loyalty: A Structural Model," Tourism Management, vol. 26, pp. 45-56, 2005.

[28] G.M.S.Dann, "Tourist motivation an appraisal," Annals of Tourism Research, vol. 8, pp. 187-219, 1981.

[29] J.Y. Kluin and X.Y. Lehto, "Measuring Family Reunion Trave Motivations," Annals of Tourism Research, vol. 39, pp. 820-841, 2012.

[30] A. Lepp and H. Gibson, "Tourist roles, perceived risk and international tourism," Annals of Tourism Research, vol. 30, pp. 606-624, 2003.

[31] N-S. Kim and L. Chalip, "Why travel to the FIFA World Cup? Effects of motives, background, interest, and constraints," Tourism Management, vol. 25, pp. 695-707, 2004.

[32] E.L. Jackson, D.W. Crawford, and G. Godbey, "Negotiation of leisure constraints," Leisure Sciences, vol. 15, pp. 1-11, 1993.

[33] B. Carroll and K. Alexandris, "Perception of Constraints and Strength of Motivation: Their Relationship to Recreational Sport Participation in Greece," Journal of Leisure, vol. 29, pp. 279-299, 1997.

[34] C.H.C. Shu and S.K. Kang, "Chinese Urban Mature Travellers Motivation and Constraints by Decision Autonomy," Journal of Traveler and Tourism Marketing, vol. 26, pp. 703-721, 2009.

[35] M.J. Khan, S. Chelliah, F. Khan, and S. Amin, "Perceived risks, Travel constraints and visit intention of young women Travelers: the moderating role of Travel motivation," Journal Tourism and Hospitality, vol. 74, pp. 726-733, 2018.

[36] M.J. Khan, S. Chelliah, and S. Ahmed, "Intention to visit India among potential Travellers: Role of Travel motivation, perceived Travel risks, and Travel constraints," Tourism and Hospitality Research, vol. 1, pp. 3 12,2018 